Biological Transformation of Wood by Microorganisms. W. Liese (Ed.), Springer-Verlag, New York, 203 p., 1975, \$17.00.

The volume compiles 16 papers presented during 4 symposia and a discussion session on Wood Products Pathology at the 2nd. International Congress of Plant Pathology, September 10-12, 1973, Minneapolis, U.S.A.

Symposium I - Interaction of $\mathrm{Mi}$ croorganisms During Wood Decay: "Biology of Decay and Wood Quality" (A. Shigo, 64 ref.), presents a model of the decay process, developed by Shigo, and describes an electrical device for assessing the degree of decay. "Colonization of Wood by Fungi" (J.F. Levy, 37 ref.) discusses the physiological and ecological aspects of colonization "Colonization of Wood by Soft-Rot Fungi" (J.A. Butcher, 20 ref.) reports observations on colonization of Pinus radiata D. Don sapwood by softrot fungi. "Succession of Microorganisms during Wood Decay" (A. Käärik, 26 ref.) discusses the successions of fungi colonizing dead wood in contact with soil. "Antagonistic and Synergistic Effects for Biological Control of Decay" (M.A. Hulme and J.K. Shields, 12 ref.) summarizes the authors' own research on organism interaction in wood, and examines practical implications.

Symposium II - Bacterial Degradation of Wood: "Bacteria Associated with Wood in Ground Contact" (J.F. Levy, 9 ref.) presents preliminary results of investigations on the subject. "Micromorphology of Bacterial Attack" (W. Liese and H. Greaves, 48 ref) and "Economic Aspects of Bacteria in Wood" (R.S. Smith, 35 ref.), review the effects of bacterial attack on the varied properties and utilization of wood.

Symposium III - Decay of Resistant Wood: "Natural Decay Resistance of Wood" (W. Da Costa, 10 ref.), reviews topics such as methods of evaluation. causes and practical significance of natural resistance, and points out research needs. "Decay of Chemically Treated Wood" (M.P. Levi, 19 ref.) discusses causes of failure of treated wood and presents results of his own studies on the interaction between Poria sp. and a copper-chromearsenate preservative. "Micromorphology of Decay in Preservative Treated Wood" (A.F. Bravery, 6 ref.) describes observations made on wood exposed to pure cultures of wood decaying fungi.

Symposium IV - The Enzymatic Mechanisms of Deterioration Processes: "Enzymic Mechanisms of Cellulose Degradation Caused by the Rot Fungus Sporotrichum pulverulentum" (K.E. Erickson B. Pattersson and W. Westermark, 7 ref.) presents results of authors' investigations. "Chemistry of
Lignin Degradation by Wood-Destroying Fungi" (T.K. Kirk, 11 ref.) reports recent progress in the field. "Polysaccharases and the Hydrolysis of Insoluble Substances" (E.T. Reese, 32 ref.) reviews the subject focusing on recent concepts of enzymatic hydrolysis of cellulose.

Discussion Section: "Extension: an Obligation of all Wood-Products Pathologists to Society" (M.P. Levi and E.B. Cowling) discusses the duty of wood pathologists to disseminate existing knowledge about the prevention and control of wood deterioration. The final item in the book is a "Partial List in Extension Publications on Recognition, Prevention and Control of Fungal Attack of Wood Products" (M.P. Levi and E.B. Cowling).

The book, produced by offset printing on good quality paper, can be recommended to libraries and to those doing or interested in research in biodegradation of wood.

\section{H. H. Unligil}

Research Scientist

Eastern Forest Products Laboratory

Ottawa, Ontario

Interpretation of Landforms from Aerial Photographs. Nürettin Keser, British Columbia Forest Service, Victoria, 219 p., 1976, $\$ 10.00$.

Landform identification is the master key by which to unlock the secrets of landscapes: for foresters it is, or should be, the foundation of forest resource management in general and of silviculture, growth and yield work, and forest engineering in particular. This book by the late $\mathrm{Dr}$. Keser is a first class aid to that end.

The book was prepared with particular reference to the identification and interpretation of land forms in British Columbia, but it should find much wider applications geographically.

In a valuable 26-page introductory chapter, the elements of aerial photo patterns (topography, drainage, gray tone, erosion, vegetation, etc.) are described with the help of line drawings, photographs and legend. Here, as in the main body of the book, stereo pairs of $5 \mathrm{~cm} \times 5 \mathrm{~cm}$ photos face, on the opposite page, a line diagram locating the feature(s) present, together with a legend that includes: original scale, reduction, photo number, map reference, general location, and primary and secondary features. Primary features comprise the landforms under each particular section, e.g. fluvial, aeolian, etc.; secondary features refer to the landforms under general headings such as organic or mass movement. Details of map references, coordinates, and date of photo- graphy are given in an appendix.

All the photos used were $25 \mathrm{~cm} x$ $25 \mathrm{~cm}$ black and white prints, mostly at scales of $1: 15840,1: 31680$, or $1: 63360$, from which "stereo-pairs were obtained by photographing the appropriate sections and mounting the reductions in stereo".

The relationships between bedrock types and landforms are considered in a very useful table as well as in stereo pairs, line drawings, and descriptive legend.

The following landform types are then considered; Ice-glacier; Glacial; Glaciofluvial; Fluvial; Marine and Lacustrine; Aeolian; Organic, Periglacial; and Mass Movement. Each section concludes with a glossary of selected terms.

While the photographs lack the brilliance of those in, say, Mathur and Gartner's "Principles of Photo Interpretation in Highway Engineering Practice" (Ontario Department of Highways, 1968,236 p.) they are mostly adequate for showing the intended features, and the 144 stereo pairs of photos constitute a collection of great value and utility, supported as they are by excellent interpretive data.

\section{R. F. Sutton}

Tree Farm Business Management, 2nd edition. James M. Vardaman, WileyInterscience, New York, 213 p., 1978, U.S. $\$ 13.95$.

This publication is designed to serve the needs of the owners of tree farms and farm woodlots, to help them manage their forest and operate their business in an efficient, effective way. It is not designed to replace the private consulting forester or the government forest extension specialist, but rather to show where these and other professionals can assist the owner to avoid pitfalls and gain the most economic benefit.

Among the subjects dealt with are the establishing of property boundaries and the posting of land to reduce trespass, the preparation of a forest inventory for management planning, the handling of timber sales, the question of mineral, wildlife and water rights, and the assistance that specialists can provide in each of these areas. Questions with respect to taxation, insurance, loans, and sales of timber land are explored, admittedly within the context of American practice and legislation, but they help to provide the Canadian owner with an overview of the alternatives open to him, and a basis for understanding the recommendations of his fiscal advisor in these fields.

The book draws it all together through the medium of a case history 
of a tree farm property.

The professional forester looking for an in-depth study of tree farming will not find what he is looking for in this publication. Rather what he will find is a publication that he can recommend to his client that will show the client what he can do himself, and what professional advice he should seek before starting an undertaking.

It is clearly and simply written with an absolute minimum of technical jargon that would confuse the nonprofessional. The author has conducted a successful forestry consulting business in the southeastern U.S.A. for over a quarter-century and one can understand his success in the clarity of the instructions he gives.

With the overriding proviso that this publication is based upon American legislation and government fiscal practice, and must be adjusted where Canadian practice differs, I would recommend that extension foresters and consulting foresters dealing with tree farmers examine this publication for reference to their clients.

\section{N. L. Kissick}

Professor,

Dept. Forest Resources

University of New Brunswick

Ecology and Management of Anima! Resources. J. Roger Bider, Eric Thompson, and R. W. Stewart, EZAIM: écologie de la zone de l'aéroport international de Montréal, Les Presses de I'Université de Montréal, 246 p., 1976, $\$ 12$.

The extent of the Mirabel P.Q. airport land expropriations, some 36000 ha, is largely unappreciated outside of the area immediately affected. The size of the undertaking was enough to cause the federal government, beginning in 1969 , to finance jointly through the National Research Council and the Canada Department of Transport a series of ecological studies of the area. Research on the project EZAIM was carried out under the direction of Professor Pierre Dansereau. Eight major publications in French have appeared: that under review is one of two in English.

The report is in three sections: the development of the matrix concept and its application to the Mirabel zone; a description of the site where the animal ecology work was concentrated, the methods, and the results; and information on species or speciesgroup combinations relevant to a broad range of developers. The term "matrix" as used by Bider et al. "is not meant to have either the botanical connotation of intercellular substance or the mathematical one indicating an orderly array of elements. It is simply that which gives form to a space or area". Thus, "much to the sorrow of purists" Bider et al. can call the stone pile, the sand dune, or the beechmaple forest a matrix of the animal community.

Most of the data were obtained by using the sand-transect technique. This in its simplest terms consists of determining the time, place, and species of animal activity by means of observing (and identifying) spoor made on beds of sand laid down as transects. Five major $61 \mathrm{~m}(200 \mathrm{ft})$ transects $61 \mathrm{~cm}(2 \mathrm{ft})$ wide were established, three in open fields (sand, clay, and muck), one in maple forest, and one in coniferous forest. The transects were read every two hours, night and day, when the location of animal crossing tracks were recorded and the tracks erased. The absence of replication is apparently a weakness in the methodology, but presumably this point was taken into account when the work was being planned. No attempt seems to have been made to analyze the results statistically. Consequently the extent of variation in animal behaviour cannot be inferred.

Nevertheless, a great amount of integrated information is presented about the 107 species of vertibrates (7 amphibians, 4 reptiles, 27 mammals, and 69 birds) and 9 groupings of invertebrates that were found to inhabit the study area: Earthworms; Slugs; Spiders; Pillbugs: Centipedes; Milipedes; Crickets and Grasshoppers; Beetles; and Caterpillars. For the wildlife researcher or wildlife photographer, the clear exposition of the circadian rhythms of animal activity is invaluable.

In his prefatory remarks, Prof. Dansereau notes that "This report contains a great wealth of new observations, a description and application of an ingenious and useful methodology, and a number of pointed recommendations to the managers of the [airport] project." A better one sentence review would be difficult to imagine.

\section{R. F. Sutton}

Growth of Forests in Canada Part I: An Annotated Bibliography. A. Bickerstaff and S.A. Hostikka, Canada Dept. Fish. and Envir., Canadian Forestry Service, Forest Management Institute, Ottawa, Information Report FMR-X-98, 197 p., 1977. Available Free from: Institute, 396 Cooper St., Publications, Forest Management, Ottawa, Ont. K1G $3 Z 6$.

This bibliography summarizes references relating to growth of forests in Canada during the period 1936 to 1975 . Its scope is further limited to studies "relating to growth, or yields at specified ages, of naturally established stands that have generally been unmanaged." Studies dealing with increased yields possible under intensive management and single tree growth studies are generally not included.

The bibliography is arranged alphabetically by author, but a comprehensive subject cross-reference list is also included. Numerical data summaries are included as part of the annotation for many studies. Measurement units are those of the original study. No conversion to metric units is provided.

In addition to the bibliography there is a short historical summary of the development of growth studies in Canada from the late 1800's to 1975. An interesting historical summary together with the 600 plus references provide a comprehensive starting point for researchers and practicing foresters interested in growth of unmanaged stands in Canada.

\section{Stephen J. Titus}

Assistant Professor

Department of Forest Science

University of Alberta.

Soil Testing and Plant Analysis. Re. vised edition. Leo $M$. Walsh and James D. Beaton (Eds.), Soil Science Society of America, Madison, Wisc., 491 p., 1973, \$8.00 (members, first copy only), $\$ 10.00$ (nonmembers), plus $50 \varnothing$ per order for orders outside USA.

Cunctation is a condition that seems to strike some people merely in consequence of their having agreed to review a book. Thus, by the time a review (not necessarily by the person first approached) appears in print, the book may not be exactly hot off the press. However, books as good as Soil Testing and Plant Analysis are well worth bringing to the readership's notice, even 5 years after publication.

The book summarizes "current knowledge and experience on the use of soil and plant analysis as aids in appraising nutritional conditions and in predicting fertilizer needs".

To describe the purview of the book, the words used by Philip F. Low (then President of the Soil Science Society of America) in his foreword can hardly be bettered: "By modern chemical methods it is possible to analyze for the nutrient elements in a soil or plant sample with great accuracy. Chemical analysis poses no significant problem. Problems arise, however, in securing representative samples, in devising methods that will accurately reflect nutrient availability, in calibrating the results of existing methods with crop responses, in making fertilizer recommendations based on these results, and in standardizing procedures. Fortunately, these problems have been receiving attention by soil scientists, agronomists, and plant scientists. As a result, our understanding of many of the topics discussed in the first edition of this publication has increased rapidly. As understanding increases, changes occur in methods, recommendations, etc. The purpose of this publication is to bring these changes into focus and to update the information available on soil testing and plant analysis". 
Eight of the 27 chapters deal with specific non-forest crops, but all of the others have relevance to forestry, directly or indirectly: Opportunities to improve soil testing programs; Principles of soil testing; Factors affecting the availability of nutrients to plants; Interpretation of soil test results; Experimental methods for correlating and calibrating soil tests; Field sampling for soil testing: Testing soils for $\mathrm{pH}$ and lime requirement; Testing soils for nitrogen; Testing soils for phosphorus; Testing soils for potassium, calcium, and magnesium; Testing soils for zinc, copper, manganese, and iron; Testing soils for sulphur, boron, molybdenum, and chlorine; The changing philosophy of soil test interpretation; Plant analysis, problems and opportunities; Principles and practises in plant analysis; Sampling, handling, and analyzing plant tissue samples; Plant analysis as an aid in fertilizing forests (by Professor Al Leaf); Use of data processing in soil testing and plant analysis; Operation and management of a commercial soil testing and plant analysis laboratory.

The intended audience includes the operators of laboratories, industrial agronomists, extension workers, college teachers and students, and scientists in other fields such as botany, forestry, ecology, and environmental science. This 5-year-old book is not out-of-date and would benefit them all.

\section{R. F. Sutton}

The Lost Patrol. Dick North, Alaska Northwest Publishing Co., Anchorage: distributed in Canada by Hurtig Publishers, Edmonton, Alberta, 138 p., 1978, $\$ 4.95$.

With all our modern modes of trans. portation, it is hard to imagine a trek of close to 500 miles during the middle of winter, over some of Canada's most desolate northern country. For the men of the Royal North-West Mounted Police this was a yearly occurrence. The trail on which four men lost their lives started at Fort McPherson in the Canadian Arctic and ended at Dawson City, Yukon Territory.

In The Lost Patrol, Mr. North has captured the grandeur of the Canadian wilderness and the enormous odds faced by these heroic men.

The book focuses on Inspector Francis J. Fitzgerald, leader of The Lost Patrol, and traces his career in Canada's North. A vivid day by day account of the patrol of 1911-1912 is presented, including details of food supplies and caloric intake, temperature, and wind chill. Every possible factor has been explored to account for the tragic ending.

The book is based on factual experiences by men who themselves made the trip and knew the men of The Lost Patrol.
Mr. North illuminates a fascinating fragment of Canadian history. For anyone who loves the outdoors, and for anyone who would like to learn more about our great country, The Lost Patrol is must reading.

\section{J. R. Ramakers}

Chemist

Great Lakes Forest Research Centre Sault Ste. Marie, Ontario

Soils and Soil Fertility. 4th edition. Louis M. Thompson and Frederick, Troeh, McGraw-Hill, New York, 516 p., 1978, \$21.60.

Like the third edition of this very sound text (reviewed in the Forestry Chronicle Vol. 50 No. 5 pp. 201-202). the fourth edition "is intended for use as a text for the introductory course in soils for students in agriculture and related sciences". The new edition, 20 pages longer and two thirds more expensive than the third which appeared just 5 years ago, represents an extensive updating with the incorporation of considerable new material, notably on soil pollution and fertilizer usage. Also, many minor clarifications and amplifications throughout have improved an already unusually clear text.

The index is a decided improvement over that furnished for the third edition.

Owners of the third edition would probably opt to invest their money elsewhere, but for others who seek a clear and authoritative overview of these vital subject matters this book would serve admirably.

\section{R. F. Sutton}

Wald, Wachstum und Umwelt. G Mitscherlich, 3 volumes (in German): Volume I. [Form and Growth of a Tree and Stand], 2nd edition. 142 p., 1977, DM32.80 (\$18.00); Volume II. [ Forest Climate and Water Relations]. 365 p. 1971, DM78.50 (\$42.00); Volume III. [Soil, Air and Production]. 352 p., 1975, DM88.00 (\$49.00). Sauerländer's Verlag, Frankfurt am Main, West Germany.

The aim of this book: "Forest, growth and environment" is to clarify the dependence of forest growth on environmental conditions and at the same time to explain the interactions between the forest and its environment. For this purpose, the author used the results of investigations from almost all European countries (not only those from central Europe, but also those from boreal forest in Norway, Sweden, Finland, and European U.S.S.R.) as well as from Canada, the U.S.A., and Japan. Numerous examples, supported by tables. illustrations, and excellent photographs are used to elucidate the relationships.

The first volume deals with the crown, the root system, and growth of single trees and of stands. Chapter 1 of this volume provides the reader with the underlying principles, both silvicultural and economic, necessary to appreciate the complex interrelationships of the forest and its environment. It describes crown forms and structures, shading of the soil, foliage of a single tree and stand, and the relation betwen the crown of the tree and timber growth.

The next chapter deals with the development of the root system, root distribution, and root growth. Successive chapters deal with the description and development of height, diameter, basal area, and volume growth of tree and stand. The problems of stand establishment and treatment, especially in mixed stands, are also discussed.

\section{ONTARIO MINISTRY OF} NATURAL RESOURCES

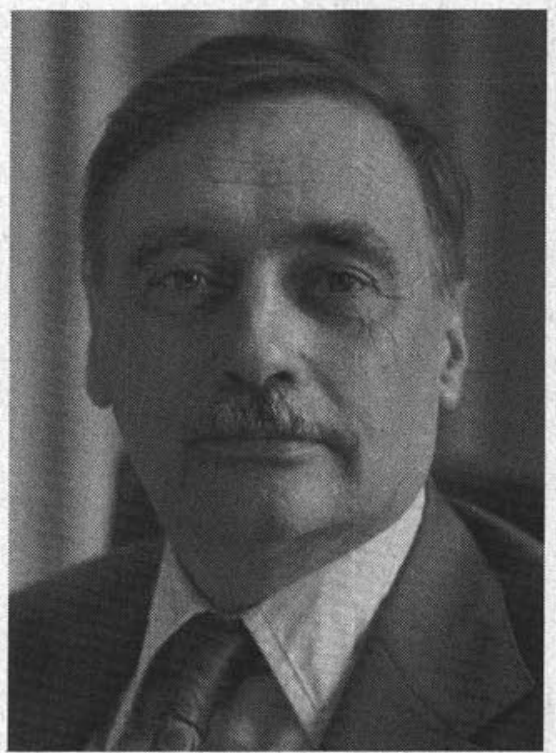

Kenneth A. Armson

The Hon. James A. C. Auld, Ontario Minister of Natural Resources, announces the appointment of Kenneth A. Armson as special adviser on forest regeneration.

Mr. Armson, author of the Armson Report on Forest Management in Ontario, moves to the Ministry from the University of Toronto where he was professor of forestry.

For the past year, Mr. Armson has been engaged on a consulting basis in ministry negotiations on regeneration with Ontario's 10 major pulp and paper companies, in implementation of a key recommendation in his Report.

Mr. Armson holds an Honors B.Sc. in forestry (U. of T.) and a Diploma of Forestry from Oxford. He became a lecturer at the $U$. of $T$. in 1952, and full professor in 1968. Mr. Armson has written more than 40 scientific papers on forestry and done consulting studies for private companies as well as various provinces.

$\mathrm{He}$ has been a director of the Canadian Institute of Forestry, president of the Ontario Forestry Association and president of the Ontario Professional Foresters Association. 
Volume II deals largely with an explanation of the relationship between tree species and forest treatments. As well, the connections between forest climate and the water regime in the forest are explained. In this volume the variable site factors are discussed in detail. Wind may serve as an example of the kind of detail presented by the author. Various kinds of wind, their daily course, velocity, and their effect on the growth and form of the crown and trunk of the tree are described. A description is given of how the wind velocity increases with the height of the tree and how it decreases from the edge of the forest towards the interior. As well, a detailed account is given of the research results of the recent, extensive storm catastrophes, their causes, and possibilities for prevention. In addition the problem of radiation and its effect on increment is discussed, as well as the effect of air and soil temperature, especially in connection with frost damage.

A large part of this volume is dedicated to the problem of air humidity, precipitation (interception, runoff, evaporation, etc.), and the general water balance in the forest. In these chapters, theoretical discussions are presented which are supported by numerous research publications from various countries, including those from the Scandinavian countries and European U.S.S.R. The research projects are mostly field projects, performed under different site and stand conditions and under different treatments, such as small and large clear cuttings, thinnings, and regeneration cuttings. Students specializing in water management and practicing field foresters should find much useful information in this volume.

In volume III, the part of the book dealing with forest soils is written entirely by Professor Dr. Wolfgang Mole. This section contains the following paragraphs: Inorganic basic material; Soil characteristics significant for quality of forest soils; Nutrients as growth factors; Control of nutrient supply; Replenishment of nutrient reserves in soils; Filter function of forest soils; Soil amelioration (e.g. stagnant water soils, marginal agricultural soils, importance of -mycor rhiza, control of soil erosion, etc.).

The problems of nutrition and especially the filtering capacity of forest soils against the damaging effects of herbicides, pesticides, oils, spraying mixtures, etc. are described in detail. Examples. techniques, and results of amelioration and fertilization are also discussed.

The chapter dealing with photosynthesis and respiration as a basis for growth and its dependence on environmental conditions is, in my opinion, too long and too scientific, especially for practicing foresters. In a special chapter, devoted to total production (biomass) the interdependence of environmental and nutrients factors and growth of roots, trunk, and branches is presented.

In the last chapters of this volume, a number of examples of nutrient budgets (e.g. loss and/or gain of nutrients by harvesting, decay or destruction of the biomass by insects, fungi, fire, wind, snow or other agents in the complex forest ecosystem) are described and explained.

At the end of this exceptional work, the author tries to present several methods of model construction - another complex and difficult but necessary task. Of this Mitscherlich, in his last sentence, has this to say: "It is necessary to conceive the forest with the growth and environment as an entirety in spite of its multiplicity."

If a review has to contain critical remarks, it is difficult to find them for this book. One very important disadvantage is the high price of the book, victim of the declining value of the Canadian dollar.

In spite of this fact, the book deserves the widest possible circulation and it is therefore a pity that an expensive layout was chosen. A much cheaper paperback edition, if possible, translated in English would be most welcome.

After that, I nevertheless dare say that this book should be in the private library of every lecturer, research forester, and practicing forest manager.

\section{Leo Vidlak}

Lakehead University

School of Forestry

Thunder Bay, Ontario

The Enterprise, Wisconsin, Radiation Forest, Radioecological Studies. J. Zavitkovski (Ed.), Energy Research and Development Administration, Technical Information Centre, Oak Ridge, Tennessee; Report TID-26113-P2, 211 p., 1977, U.S.\$7.60 within North America, $\$ 15.00$ elsewhere.

This is the second of the two volumes reporting on the Enterprise research project. The first, published in 1974 (T.D. Rudolph, ed.), dealt with the preirradiation ecological studies initiated in 1969; the present volume gives results of the radioecological research conducted by staff of the Institute of Forest Genetics, Rhinelander, and by cooperators from several other institutions.

The project is one of a few similar ones in forests of the temperature zone and in the tropics. The original plan was to study effects of five seasonal gamma radiation exposures on several typical North American forest ecosystems and a 5-year chronic exposure of an aspen ecosystem. However, the project was cut short and only one growing-season exposure was completed before the project was phased out. In spite of this, a wealth of valuable information is contained in the 20 papers (designated chapters) of this book.

The book covers a broad range of ecological studies. The first chapter describes radiation patterns and dosimetry in the forest and attenuation by vegetation and topography. The next two deal with irradiation effects on the physical environment of the forest. The following eight chapters, comprising about one-third of the book, are devoted to effects on the forest vegetation, including studies on radiosensitivity, structure, production and growth of shrubs and trees and effects on lichens and herbs. Phenological studies of herbs and trees and pattern of shoot and radial growth of trees in relation to gamma radiation are presented in four chapters. Radiation effects on small mammal populations and nesting avifauna are treated thereafter. This is followed by two laboratory studies on radiosensitivity of Populus tremuloides seed and gas exchange, dry weights and chlorophyll contents of seedlings of this species grown from irradiated seeds.

The last 10-page chapter by the editor is a good summary of results obtained in the project between 1969 and 1975. In addition to dealing with the subject matters already listed, a comparison is made of radiosensitivity of the northern deciduous forest with that of other plant communities.

The papers are generally of high quality and most of them have good discussions and are well referenced. They will, therefore, serve as valuable introductions to the fields covered Those with a serious interest in forest ecology should at least read the last summary chapter; other chapters will then likely attract their attention.

\section{H. Brix}

Research Scientist

Pacific Forest Research Centre Victoria, B.C.

Banff National Park. D. M. Baird, Hurtig Publishers, Edmonton (in co-operation with Parks Canada and the Geological Survey of Canada), 235 p., 1977, \$5.95 (sewn paperback).

Jasper National Park. D. M. Baird, Hurtig Publishers, Edmonton (in co-operation with Parks Canada and the Geological Survey of Canada), 159 p., 1977, \$4.95 (sewn paperback).

Going West? West already? These two guidebooks can hardly fail to enhance your enjoyment of that exhilarating Banff-Jasper country. Light in weight but not in content, the guides should be carried at the ready by anyone travelling in the area.

The guides are easy to use. The latter part of each book - about half in the case of Jasper, and about two thirds of Banff consists of "Roadlogs and Points of Interest". In Dr. Baird's words: "As you drive through (the Park) you pass a number of viewpoints, campspots and other places where the view is especially good or where there are things of special scenic and geological interest. What you can see from each of these places is described here in a series of roadlogs, and the numbered stops can be followed on the maps...".

Some of the material in the first part of the guides is common to both, but in each 
case a well rounded, if broad, description of the geology of the Park is given. Language unfrightening to the layman is used, and necessary geological jargon is italicized and explained fully at first mention in the text.

Each book is well illustrated, mostly with black and white photographs but also with 16 pages of beautiful color photos which reveal Baird as an exceptionally able artist with the camera. For me, however, the appeal of several of the photos had been markedly diminished because they have been printed across the page fold to produce an effect comparable with that im parted to a natural scene when observed through cracked glass, spectacle lens or window pane.

A major disappointment in these guides is their complete lack of reference to vegetation. Dr. Baird does not see trees, even though they grace many of his photographs. The titles of the guides are in fact misleading and would more appropriately have been "Geology and Scenery in the National Park"

\section{R. F. Sutton}

The Land That Never Melts: Auyuittuq National Park. Roger Wilson (Ed.), Peter Martin Associates Ltd. in association with Indian and Northern Affairs, Parks Canada, and Publishing Centre, Canada Department of Supply and Services, Ottawa, 212 p., 1976, $\$ 5.95$

This is a gem of a book. The text is clear, and the illustrations are remarkably fine. The 21 bird paintings by Jean-Luc Grondin and the 75 or so colour photographs (including a series of arctic wildflowers) are excellent both scientifically and artistically.

Even if you know you're never going to find yourself on the Cumberland Peninsula of Baffin Island, this book will take you there and let you experience something of the fascination of this most northerly of $\mathrm{Ca}$ nada's National Parks.

The only adverse criticism I would offer concerns the map: a hand lens is needed for just about everything but the title - and the cartographer's name.

\section{R. F. Sutton}

Timber Tax Journal, Vol. 12(1). Forest Industries Committee on Timber Valuation and Taxation, Washington, D.C., 261 p., 1976, U.S. \$19.50. Exclusive distributor in Canada and U.S.: International Scholarly Book Services Inc., Box 555, Forest Grove,
Oregon, 97116. (Vol. 13, 449 p., 1977, U.S. $\$ 25.00$ ).

Although the Forest Industries Committee on Timber Valuation and Taxation in the USA was formed in the 1960's, problems in forest and timber taxation first became apparent during the depression years in the area of property taxation. A major study of the problem resulted in 1935 in the publication of the famous Fairchild report. The introduction in 1944 by the Federal Government of capital gains tax added further complications. The Journal issued by the present Committee deals with the various aspects of taxation of forest properties and incomes derived from them. This particular issue lists both consulting foresters specializing in forest taxation and university courses in forest taxation. As well, there is a topical index covering several hundreds of topics cumulatively for all issues of the Journal. Also, abstracts of articles in a number of national or regional journals are reprinted.

But the major thrust of the Journal is in the discussion of federal and state timber taxation, enabling legislation, litigation, and court decisions. On the federal level, a 20 page article deals with the interpretation of the timber tax treatment under section 631(a) of the Internal Revenue Code, which provides for the election of income from the sale of timber to be treated as capital gain, usually the preferred way to deal with it. Interestingly enough, elsewhere in this issue, this section was applied but after litigation disallowed in the rather detailed case of Allen Logging \& Veneer Co. v. United States. A large part of this volume deals with similar cases, some of which rank as landmarks in the application of the provisions of the Internal Revenue Code. In another section of this issue, state timber taxation receives an equal amount of attention in a summary of tax laws of all the states. At this level, the legislation deals largely with property taxes. Elsewhere, articles deal with specific topics in the form of speeches delivered at meetings. Most notably of these is the article by Tichnor, manager of the Woodlands Division of a paper company in Florida, who pleads for changes in the federal estate tax. $\mathrm{He}$ argues, quite convincingly, that the value of the current use of the land should be used in its evaluation, rather than market value.

Owing to the predominantly public ownership of the forests in Canada, the subject of taxation has not received the attention here as it has in the U.S.A. Moore's 1957 treatment of taxation in Forestry Taxes and Tenures in Canada still stands as a major authority on the subject of both property taxes and the treatment by the Revenue Department of income generated from forest exploitation. But it is high time that this study be brought up to date. Although somewhat more recent, but on the fringes of forest taxation, La Forest's 1969 book on natural resources and the Canadian constitution also is insufficient. A recent study by the CIF working group \#9 is taking the bull by the horns, but perhaps too timidly. For those concerned about the effect of the various taxes levied on forest property and the sale of timber, it would be well to study the legislation and legislative precedents in the USA as described in this Journal. Some of it makes for highly interesting reading.

\section{G. Hazenberg}

Associate Professor

School of Forestry

Lakehead University

Technical Books and Monographs, 1978 Catalog. U.S. Dept. of Energy, Office of Technical Information, 153, p., 1978, available free as T1D-4582-R13 from Technical Inf. Center, P.O. Box 62, Oak Ridge, Tennessee, U.S.A., 37830.

The following extracts from the Foreword and prefatory "To The Reader" should give a good idea as to what this catalog is all about.

"To help meet the information needs of scientists and engineers working in energyrelated fields, the U.S. Department of Energy supports an extensive technical information program...". "Technical Books... lists many of the technical books made available through [this program]... "[which] provides access to a large body of knowledge generated by ... programs as diverse as the field of nuclear medicine, the exploration of physical mechanisms at work in the environment, and the varied tech. nologies required to realize the potential of all energy sources."

"The [more than 500] books and monographs are grouped under thirteen subject categories [General Reference; Biology and Medicine; Chemistry; Computers and Mathematics; Energy; Engineering and Instrumentation; Environment; Health and Safety; Isotope Separation; Metallurgy and Materials; Physics; Reactors; Vacuum Technology]..." and the "information for each ... includes title; author and author affiliation; publisher and publication date; page count; size of book; price; availability..." and a list or description of the contents.

\section{R. F. Sutton}

